Check for updates

Cite this: RSC Adv., 2017, 7, 38257

\title{
Underlying mechanism for the modulation of apoptosis induced by a new benzoindole derivative on HT-29 colon cancer cells
}

\author{
Fatemeh Hajiaghaalipour, (D) *ab Elham Bagheri, ${ }^{c}$ Fadhil Lafta Faraj, ${ }^{\text {de }}$ \\ Mahmood Ameen Abdullab and Nazia Abdul Majid ${ }^{* a}$
}

\begin{abstract}
Colorectal cancer is the third most common form of cancer affecting both men and women around the world. The chemical and biological studies of heterocyclic compounds have been an interesting area in pharmaceutical and medicinal chemistry. A new synthetic compound namely 2-(1,1-dimethyl-1H-benzo [e]indol-2-yl)-3-((2-hydroxyphenyl)amino)acrylaldehyde, abbreviated as DBID was screened for the antiproliferation effects against the colorectal cancer cell line, HT-29 and its possible mechanism of action was elucidated. To determine the $\mathrm{IC}_{50}$ value, MTT assay was employed and further verified by the LDH release assay and apoptosis-inducing effect. DBID inhibited the proliferation of HT-29 cells and significantly increased the levels of caspase $-8,-9$ and $-3 / 7$ in the treated cells compared to untreated cells. Apoptosis features in HT-29 cells were detected in treated cells by using the AO/PI staining and flow cytometric analysis of Annexin $V$. The changes in expression of some apoptotic genes were confirmed by gene quantification using RT-PCR. The current study showed that the DBID compound exhibited chemotherapeutic activity, which was evident by significant increases in the expression and activation of caspase, up-regulation of the expression of specific apoptotic genes and exploitation of the apoptotic signaling pathways to trigger cancer cell death.
\end{abstract}

Received 5th April 2017

Accepted 29th June 2017

DOI: $10.1039 / c 7 r a 03875 e$

rsc.li/rsc-advances

\section{Introduction}

The American Cancer Society reported colorectal cancer as the third most common form of cancer in both genders around the world. Their report indicates that, for 2017 , colorectal cancer would be the third leading cause of cancer deaths in women, and the second leading cause of death in men estimating about 50260 deaths as a result from the disease. Recently, there has been a drastic increase in the number of colon cancer cases. This surge has highlighted this cancer as a health issue of serious concern, with 135430 cases of colorectal cancer being estimated and expected to be reported in $2017 .^{1}$

Age is the one of the risk factors for colorectal cancer as $91 \%$ of patients are diagnosed at 50 years of age or older. The other risk factors are personal or family history of colorectal cancer and/or polyps, known to have chronic inflammatory bowel

${ }^{a}$ Institute of Biological Sciences, Faculty of Science, University of Malaya, 50603, Kuala Lumpur, Malaysia.E-mail: sara.h.alipour@um.edu.my;nazia@um.edu.my

${ }^{b}$ Department of Biomedical Sciences, Faculty of Medicine, University of Malaya, 50603, Kuala Lumpur, Malaysia

${ }^{c}$ Department of Pharmacy, Faculty of Medicine, University of Malaya, 50603, Kuala Lumpur, Malaysia

${ }^{d}$ Department of Chemistry, Faculty of Science, University of Malaya, 50603, Kuala Lumpur, Malaysia

${ }^{e}$ Department of Chemistry, Faculty of Science, University of Diyala, Diyala Governorate, Iraq disease, and some inherited genetic manifestations. Modifiable risks factors include alcohol consumption, long-term smoking, obesity, less physical activity and high amounts of red or processed meat in diet. The standard treatment for colon and rectal cancer is surgical removal, followed by adjuvant chemotherapy or radiotherapy. For localized cancers, surgical resection may be curative. However, this therapy is just moderately successful especially for late stage cancers; therefore, new approaches to the treatment of colorectal cancer are required..$^{1-3}$

The chemistry and biological study of heterocyclic compounds have been an interesting area for a long time in pharmaceutical and medicinal chemistry. Medicinally many indole derivatives are acknowledged to have a wide range of medicinal properties. ${ }^{4-6}$

In the present study, new Schiff base 2-(1,1-dimethyl-1H-benzo [e]indol-2-yl)-3-((2-hydroxyphenyl)amino)acrylaldehyde (DBID) has been synthesized and the potential chemotherapeutic properties of DBID, as a novel synthetic compound and its possible mechanism of action was investigated on colorectal cancer cell line, HT-29.

\section{Experimental}

\section{Synthetic compound}

The new compound 2-(1,1-dimethyl-1H-benzo[e]indol-2-yl)-3-((2hydroxyphenyl)amino)acrylaldehyde (DBID) was synthesized, 
characterized and confirmed by spectroscopic techniques. These data have already been published by the same authors. ${ }^{7}$ The compound was provided by the Department of Chemistry, University of Malaya.

\section{Cell culture}

To evaluate the antiproliferative activity of DBID, a human colonic carcinoma cell line, HT-29 (ATCC® HTB-38 ${ }^{\mathrm{TM}}$ ) was purchased from the American Type Culture Collection (ATCC, VA, USA). Normal human colon cell CCD 841 CoN (ATCC® CRL$1790^{\mathrm{TM}}$ ) was provided from American Type Culture Collection, VA, USA. The HT-29 and CCD 841 CoN cells were cultured in ATCC-formulated McCoy's 5A Medium (ATCC® 30-2007 ${ }^{\mathrm{TM}}$ ) and Eagle's Minimum Essential Medium (ATCC® 30-2003 ${ }^{\mathrm{TM}}$ ), respectively. The cells were supplemented with 10\% FBS (fetal bovine serum), and $1 \%$ penicillin-streptomycin (iDNA, South America), incubated at $37{ }^{\circ} \mathrm{C}$ in a $5 \% \mathrm{CO}_{2}$ incubator.

\section{Antiproliferative effects of DBID}

The inhibitory effect of DBID was investigated using a human colorectal carcinoma cell, HT-29 while the antiproliferative effect of DBID was evaluated by using the MTT (3-(4,5-dimethyl thiazol-2-yl)-2,5-diphenyl tetrazolium bromide) assay. ${ }^{8}$ Normal colon cell line, CCD 841 CoN was used to identify any cytotoxic effect of the compound. The cells were treated with various concentrations of the compound $\left(0-50 \mu \mathrm{g} \mathrm{ml}{ }^{-1}\right)$ for $48 \mathrm{~h}$. All the experiments were performed in triplicate. In this study 5-fluorouracil (5-FU) was used as a standard drug. The $\mathrm{IC}_{50}$ known as the concentration of the compound that caused $50 \%$ growth inhibition was determined based on the following formula;

Inhibition $(\%)=[(\mathrm{OD}$ untreated $-\mathrm{OD}$ treated $) /(\mathrm{OD}$ untreated $)]$ $\times 100$

\section{Determination of lactate dehydrogenase (LDH) release}

The release of lactate dehydrogenase (LDH) into the culture medium was assessed using a CytoTox-ONE ${ }^{\text {TM }}$ Homogeneous Membrane Integrity Assay kit (Promega, Madison, WI, USA) according to the manufacturer protocol. In this experiment, the cells were treated with different concentration of DBID for $24 \mathrm{~h}$. The lysis solution ( $9 \%$ weight/volume solution of Triton ${ }^{\circledR}$ X-100 in water) was used to determine the maximum amount of $\mathrm{LDH}$ present. The percentage of cytotoxicity was calculated by using the following formula:

Cytotoxicity $(\%)=100$

$\times[$ (sample LDH release - culture medium background $) /$ (maximum LDH release - culture medium background)]

\section{Reactive oxygen species generation}

The intracellular reactive oxygen species (ROS) generation was measured using Cellular Reactive Oxygen Species Detection Assay Kit (Abcam, Cambridge, UK; ab113851) according to the manufacturer protocol. The procedure was based on oxidation of DCFH-DA to form the fluorescent compound, $2^{\prime}, 7^{\prime}$-dichlorofluorescein (DCF) by intracellular ROS and other peroxides. The cells were treated with DBID at the different concentrations for $24 \mathrm{~h}$.

\section{Fluorescence microscopic examination}

To investigate the morphological characterization of HT-29 cells, propidium iodide and acridine orange double staining was performed where the cells were then observed under a fluorescence microscope according to the method described previously. ${ }^{\mathbf{9}, 10}$ The HT-29 cells were treated with two different concentrations of DBID for $24 \mathrm{~h}$. The harvested cells were stained with an equal volume of fluorescent dye (AOPI) and observed under a fluorescence microscope.

\section{Flow cytometric Annexin V}

The Annexin V assay was carried out using FITC Annexin V Apoptosis Detection Kit supplied from BD Pharmingen ${ }^{\mathrm{TM}}$ (ApoAlert Annexin V, Clontech, California, USA). The cultured cells in a $25 \mathrm{~cm}$ flask were treated with the $\mathrm{IC}_{50}$ concentration of DBID compound determined by MTT assay for $24 \mathrm{~h}$. The cells were then subjected with the FITC Annexin V staining protocol to measure apoptosis.

\section{Caspase activity assays}

The caspase $-3 / 7,-8$ and -9 activities was evaluated by using commercial kits purchased from Promega Company (Madison, WI, USA) according to the manufacturer's protocol. The cells were treated with different concentrations of DBID for $24 \mathrm{~h}$. Cells without any treatment, cell treated with respected caspase inhibitor and media alone without cells were used as the controls and blank.

\section{Gene expression analysis by RT-PCR}

HT-29 cells were treated with the IC $_{50}$ concentration of DBID and incubated for $24 \mathrm{~h}$ in $25 \mathrm{~cm}^{2}$ culture flasks. Total RNA was extracted with RNeasy® plus mini kit (Cat. no. 74134, QIAGEN, Germany), and assessed for quality and quantity using absorption measurements (Thermo Scientific Nanodrop 2000 Spectrophotometer, Massachusetts, USA). Reverse transcription into cDNA was performed by using Two-Step qRT-PCR kit, high capacity RNA to cDNA by Applied Biosystems, USA. The relative quantification of the genes was performed using the TaqMan ${ }^{\circledR}$ Gene Expression Master Mix by following the manufacturer's protocol. The expression of two endogenous controls ACTB (Hs99999903_m1) and GAPDH (Hs03929097_g1) were used in this study. Apoptosis-related cysteine peptidase specific primers; caspase 3 (CASP3, Hs00234387_m1), caspase 8 (CASP8, Hs01018151_m1), caspase 9 (CASP9, Hs00609647_m1), apoptosis regulator; BCL2 (BCL2, Hs00608023_m1), BCL2 associated X (BAX, Hs00180269_m1), tumor protein p53 (TP53, Hs01034249_m1) and BH3 interacting domain death agonist (BID Hs00609632_m1) were purchased from TaqMan® (MGB probes, FAM ${ }^{\mathrm{TM}}$ dye-labeled). All experimental samples were performed in biological triplicates. The $\Delta \Delta \mathrm{Ct}$ method was used 
to determine the relative expression and comparative Ct values analysis via differences between the treated and untreated groups were performed.

\section{Statistical analysis}

All experiments were carried out in triplicate, and the results were analyzed and presented as means \pm standard deviation (SD). Statistical analysis was done by using SPSS V.18.0 statistical software, Student's $t$-test. $P$-value less than 0.05 was considered statistically significant.

\section{Results and discussion}

\section{In vitro antiproliferative effect}

The colonic carcinoma cell line HT-29 was selected to determine the antiproliferative activity of the compound. In addition, CCD 841 CoN cells was included to investigate the cytotoxicity of the compound on normal colon cells. As shown in Table 1, DBID exhibited the potent antiproliferative effect against HT-29 cells $\left(\mathrm{IC}_{50}=11.85 \pm 2.7\right)$ whereas the $\mathrm{IC}_{50}$ of the compound on normal colon cells $\left(\mathrm{IC}_{50}>150 \mu \mathrm{g} \mathrm{ml}^{-1}\right)$ was significantly higher than HT-29 $(p<0.05)$. The 5-fluorouracil (5-FU) acting as the reference control showed high anti-proliferative activities against tumorigenic HT-29 cells. The findings of this study showed strong inhibitory effect of the DBID compound against the tumorigenic cell line; HT-29 without no cytotoxic effect on normal cells. The MTT assay showed that DBID at concentration of $11.86 \mu \mathrm{g} \mathrm{ml}^{-1}$ can inhibit $50 \%$ of HT-29 proliferation in vitro.

\section{The leakage of $\mathrm{LDH}$}

The cytotoxic effect of DBID compound against HT-29 cells was further verified by the LDH release assay. The measurement of the LDH release is commonly used for testing cytotoxicity based on the integrity of the cell membrane. The loss of integrity of the cell membrane leads to the leakage of LDH from the cytoplasm into the surrounding culture medium in non-viable cells. ${ }^{11}$ DBID compound induced LDH leakage in HT-29 cells when compared to untreated cells (Fig. 1). The LDH leakage from HT29 cells treated with DBID compound was significantly different at concentration as low as $10 \mu \mathrm{g} \mathrm{ml} \mathrm{m}^{-1}$ compared to the untreated cells $(p<0.05)$.

In determining the release of lactate dehydrogenase (LDH), the significant percent of cytotoxicity of DBID against HT-29 cells was shown at concentration $10 \mu \mathrm{g} \mathrm{ml}^{-1}$, which was compatible

Table 1 Antiproliferative effects and cytotoxicity activities of a new benzoindole derivative (DBID) on colon cancer cell line and normal human colon cell line ${ }^{a}$

\begin{tabular}{lrr}
\hline Compound & HT-29 & CCD 841 CoN \\
\hline DBID & $11.85 \pm 2.7$ & $189.73 \pm 4.1$ \\
5-Fluorouracil & $3.9 \pm 1.26$ & $43.8 \pm 6.3$
\end{tabular}

${ }^{a}$ Data are presented as $\mathrm{IC}_{50} . \mathrm{IC}_{50}$ is the effective concentration of the compound which was used to prevent the $50 \%$ of the cells' growth $\left(\mu \mathrm{g} \mathrm{ml}^{-1}\right)$. Results were expressed as means $\pm \mathrm{SD}(n=3)$.

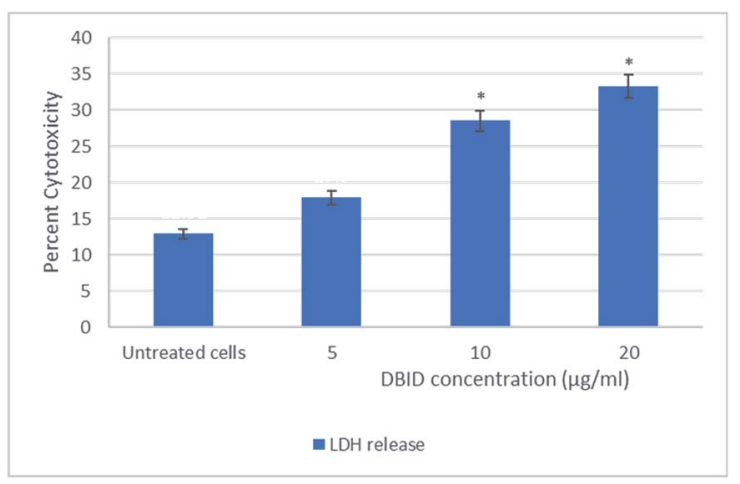

Fig. 1 Lactate dehydrogenase (LDH) release in HT-29 cells treated with different concentration of DBID compound for $24 \mathrm{~h}$. Results were expressed at means $\pm \mathrm{SD}(n=3)$. *Indicates significant differences compared to the control (untreated cells) verified by the Student's $t-$ test $(p<0.05)$.

with the $\mathrm{IC}_{50}$ value of DBID $\left(11.85 \pm 2.7 \mu \mathrm{g} \mathrm{ml} \mathrm{m}^{-1}\right)$ determined in the MTT assay. Based on the presented results, DBID compound was toxic to HT-29 cells, which resulted in a loss of membrane integrity, release of LDH into the culture medium, and generated a greater fluorescent signal in comparison with untreated cells. The anticancer effect of heterocyclic compounds has been proposed in many studies..$^{12-16}$

\section{Intracellular ROS formation}

The reactive oxygen species are produced continuously in living cells, as a result of metabolic and other biochemical reactions. Under oxidative stress conditions, excessive ROS leads to various biochemical and physiological impairments and promotes cell death. Fig. 2 illustrates the intracellular reactive oxygen species (ROS) generation in treated cells with different concentration of DBID for $24 \mathrm{~h}$ compared with untreated cells. The formation of ROS in HT-29 cells treated with the DBID compound increased in a dose-dependent manner and the strong significant production of ROS in treated cells was

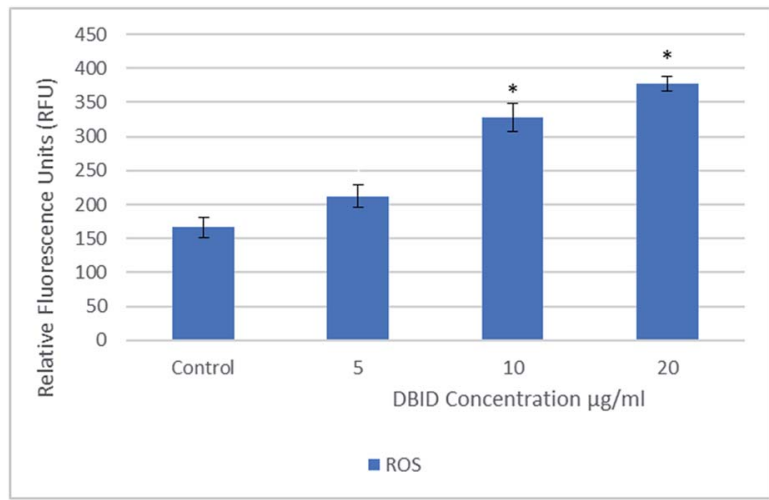

Fig. 2 Intracellular ROS generated in HT-29 cells treated with different concentration of DBID compound for $24 \mathrm{~h}$. Results are expressed as mean \pm standard deviation. ${ }^{*} p<0.05$ versus control (untreated cells) by Student's t-test. 
generated at concentration of 10 and $20 \mu \mathrm{g} \mathrm{ml}^{-1}$ upon treatment. At $5 \mu \mathrm{g} \mathrm{ml}^{-1}$ of DBID concentration treatment, a slight increase of ROS was observed.

DBID was able to elevate the production of ROS in the treated cells significantly compared with untreated cells. The ROS concentration is vital in cells and tissue. Under oxidative stress conditions, excessive ROS leads to a various biochemical and physiological impairments and promotes cell death. The important role of intracellular ROS in apoptosis induction has been reviewed previously. ${ }^{17}$ Previous studies have suggested that the reactive oxygen species are responsible as part of the signaling process for activating an important mechanism for eliminating cancer cells such as apoptosis. It has been proposed that the disproportional increase in intracellular ROS leads to release cytochrome $\mathrm{c}$ from mitochondria which trigger caspase activation. ${ }^{18-20}$ There are several anticancer agents depend on this form of cell death for their efficacy. ${ }^{19,21}$ The present results propose the apoptosis inductions through the production of intracellular ROS formation in cells treated with DBID compound.

\section{Fluorescence microscopic examination}

The occurrence of apoptosis was qualitatively investigated. This involved the use of the two dyes of AO/PI and fluorescence microscopy. AO penetrates the plasma membrane of viable and early apoptotic cells where stained nucleated cells would generate a green-coloured fluorescence while PI would only enter the cells with compromised membranes and later produce an orange/red fluorescence intensity in dying, dead, and necrotic nucleated cells stained with PI. ${ }^{22,23}$

As shown in Fig. 3, a normal morphology with green nuclei and also an intact structure was observed in untreated cells while the cells treated with DBID showed bright green nuclei indicating the condensation of nucleic chromatin and interpolated propidium iodide (orange fluorescence) amongst the fragmented DNA and nuclear fragmentation. Apoptosis characteristics e.g. cell shrinkage, membrane blebbing and chromatin condensation were observed in DBID treated cell. Fig. 3 shows remarkable morphological changes of the HT-29 cells treated with DBID in both concentrations (Fig. 3B and $\mathrm{C}$ ) in apoptotic bodies. The results of this study proved that the activation of the caspase pathway may trigger apoptosis in HT-29 cells that had been treated with DBID.

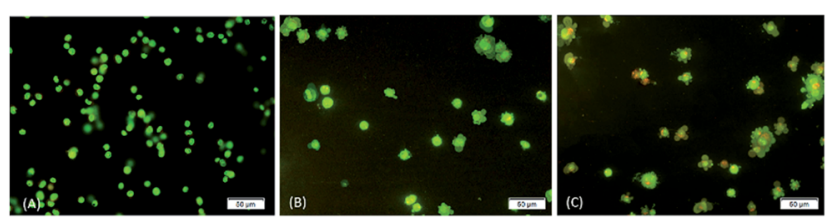

Fig. 3 Morphological charges of untreated and DBID-treated HT-29 cells. Fluorescence microscopic examination by using double fluorescent dye (AO/PI) staining method on cells treated with DBID after $24 \mathrm{~h}$ incubation. From left to right; (A) untreated HT-29 cells, (B) $10 \mu \mathrm{g} \mathrm{ml}^{-1}$ DBID-treated, (C) $20 \mathrm{\mu g} \mathrm{ml}^{-1}$ DBID-treated.

\section{Annexin V assay}

Annexin V/propidium iodide (PI) flow cytometry was performed to confirm the presence of apoptosis. Annexin $\mathrm{V}$ is used to detect apoptosis by targeting the loss of plasma membrane asymmetry by specific interaction with phosphatidylserine (PS) on the cell surface. The intact cell membrane of viable cells is not permeable to $\mathrm{PI}$ and represent $\mathrm{AV}-\mathrm{PI}-$ staining. The loss of plasma membrane asymmetry and strong affinity of AV-FITC with PS leads to AV+/PI- staining in the early apoptotic cells, whereas $\mathrm{AV}+/ \mathrm{PI}+$ represents late apoptotic. Necrotic stage is representing by $\mathrm{AV}-/ \mathrm{PI}+$ as a result of $\mathrm{PI}$ penetration through the membranes and intercalate into nucleic acid due to loss of plasma and nuclear membrane integrity. The flow cytometry of Annexin V results and analysis are presented in Fig. 4(A and B). The cells treated with DBID significantly underwent apoptosis after $24 \mathrm{~h}$ post treatment compared with untreated cells $(p<$ 0.05 ). More than $40 \%$ of treated cells were at the early and late stages of apoptosis after $24 \mathrm{~h}$ (Fig. 4(B)). In addition, treatment with DBID showed no concurrent increase in necrotic cells. Consistent with AOPI stating results, flow cytometric Annexin V analysis of DBID treated cells clearly demonstrated that antiproliferation and apoptosis in HT-29 treated cells are closely related.

\section{Cellular caspase activities (caspase $-9,-8$ and $-3 / 7$ )}

The activation of caspases $-9,-8$ and $-3 / 7$ in HT-29 cells treated with different concentration of DBID compound were determined. Each of these assays were linear with respect to the number of cells undergoing apoptosis in the experiment. As shown in Fig. 5(A-C), the compound (DBID) significantly increased the activities of caspases $-9,-8$ and $-3 / 7$ in HT-29 cells,
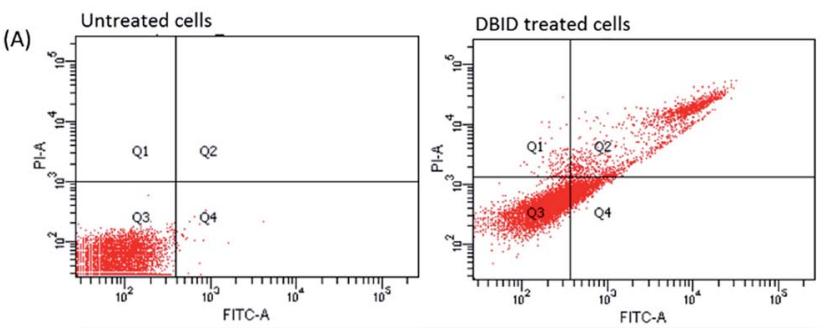

(B)

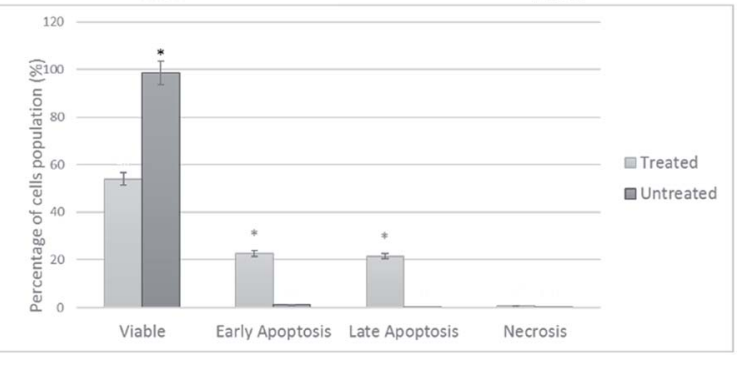

Fig. 4 Flow cytometric Annexin V/PI. (A) HT-29 cells (untreated and DBID treated) were stained with Annexin V/PI (B) flow cytometric analysis of the percentage level of the four quadrants representing viable cells (Annexin $\mathrm{V}-\mathrm{PI}-$ ), early apoptosis (Annexin $\mathrm{V}+\mathrm{PI}-$ ), late apoptosis (Annexin $\mathrm{V}+\mathrm{PI}+$ ) or necrotic (Annexin $\mathrm{V}-\mathrm{PI}+$ ) stages in treated and untreated cells. Values shown are percentages of each quadrant $* p<0.05$ 


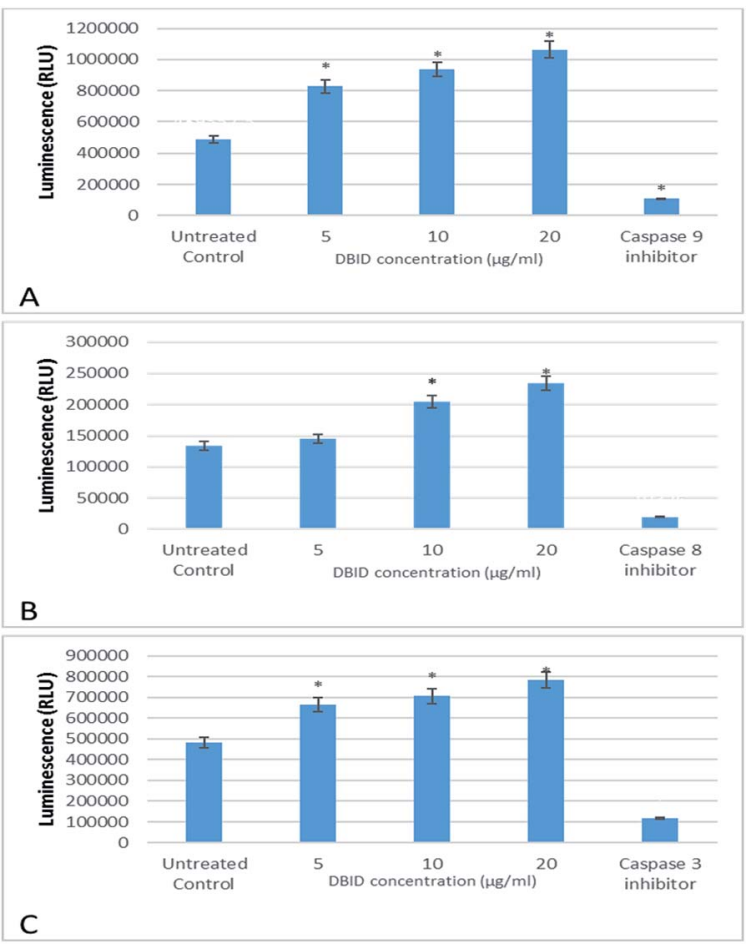

Fig. 5 The effect of DBID on caspase activity in HT-29 colon cancer cells. The activity of (A) caspase- 9 (B) caspase- 8 and (C) caspase-3/7. Data shown are the mean values of the triplicates. *Indicates significant differences from untreated cells $(p<0.05)$

compared with the control in a dose-dependent manner $(p<$ 0.05). Fig. 6 represents the caspase activity fold changes over control cells. The caspase-8 activity was significant only at the concentration of 10 and $20 \mu \mathrm{g} \mathrm{m}{ }^{-1}$ of the compound $(p<0.05)$. The activity of caspase $-3 / 7$ and -9 in treated cells was steadily increased in a dose-dependent manner and statistically significant compared to the untreated cells $(p<0.05)$. Apoptosis is typically accompanied by the activation of caspase proteins. Caspases are cysteine-aspartic proteases or cysteine-dependent aspartate-directed proteases, a family of cysteine proteases that play essential roles in apoptosis. Caspase-9 is known as an indicator for the activation of a branch caspase cascade, namely, the intrinsic (mitochondria mediated) apoptotic pathway and caspase-8 is a marker for the extrinsic (receptor) pathway of apoptosis. Caspase-3 is activated in apoptotic cells by both the extrinsic and intrinsic pathways. ${ }^{24}$ The results of caspase activity suggested that the intrinsic or mitochondrial pathway were mainly mediated by the activation of caspase-9, and also the extrinsic or death receptor pathway mediated by the activation of caspase-8, triggered the apoptosis induction in treated cells. These results revealed that the caspase -9 and -8 as initiator caspases and caspase-3/7 as executioner caspases were involved in the mechanism of apoptosis induced by the compound on HT-29 cells. Consistent with this result, the cytotoxic effect and antiproliferative activity of heterocyclic compounds synthetic compounds, against colon cancer cells by activating caspases and inducing apoptosis have also been shown in a previous study. ${ }^{25-27}$

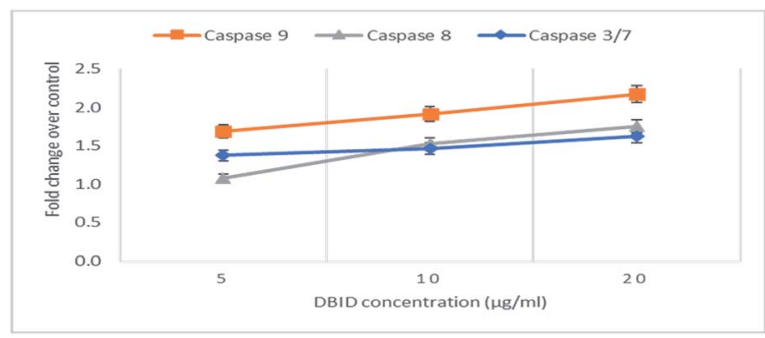

Fig. 6 The fold change in caspase activity of HT-29 cells treated with DBID at different concentrations.

\section{Gene expression}

The HT-29 cells were treated with the $\mathrm{IC}_{50}$ concentration of the DBID compound to further investigate the possible pathways involved in antiproliferative effect of the compound at gene expression level using real time-PCR technique.

The gene expression study of some of these genes involved in apoptosis showed the overexpression of TP53, BID and BAX in HT-29 cells. Furthermore, the genes encode the cysteineaspartic acid protease (caspase) family e.g. CASP9, CASP8 and CASP3 were also up-regulated in this study. Fig. 7 shows that CASP3, CASP9, CASP8, TP53, BAX and BID were significantly overexpressed in treated HT-29 cells by a mean factor of 2.48 , $2.79,1.67,3.7,4.1$ and 1.47 , respectively. The apoptosis regulator gene, BCL2 was slightly downregulated in DBID treated cells by a mean factor of 0.89 .

The activation of caspases is known as a hallmark of apoptosis which proposals new therapeutic agents for the treatment of cancer cells. ${ }^{28-31}$ The p53 tumor suppressor gene (TP53) encodes the tumor protein p53, a transcriptional factor that binds to DNA and activates the expression of downstream genes, which mediates cellular stress responses i.e. cell-cycle arrest, senescence and apoptosis. ${ }^{32}$ BID, a pro-apoptotic member of the Bcl-2 family, mediates the activation of caspase- 9 by caspase-8 through the mitochondrial pathway. The ability of DBID to activate BAX can be inhibited by the antiapoptotic Bcl-2 proteins resulting in apoptosis inhibition by sequestering DBID, leading to reduced Bax activation. ${ }^{33,34}$

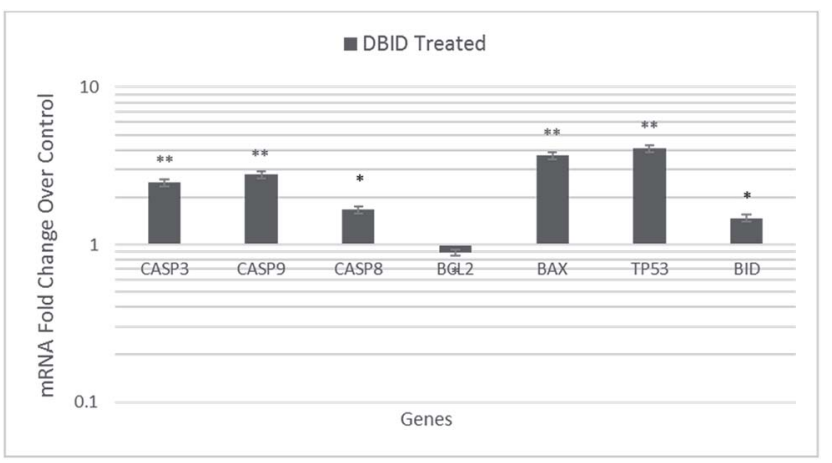

Fig. 7 Gene expression analysis of HT-29 cells treated with the $\mathrm{IC}_{50}$ concentration of DBID for $24 \mathrm{~h}$. Results are expressed as mean \pm standard deviation of three replicates $* p<0.05, * * p 0.01$. 
Moreover, the intrinsic or mitochondrial pathway is mediated by the alteration of the pro-apoptotic (Bax) and anti-apoptotic $(\mathrm{Bcl} 2)$ ratio. $\mathrm{Bcl} 2 \mathrm{~L}$ ( $\mathrm{Bcl} 2-\mathrm{Like}), \mathrm{BclXL}(\mathrm{Bcl} 2$ related protein long isoform) and other anti-apoptotic $\mathrm{Bcl} 2$ family members reside in the outer mitochondrial membrane and prevent cytochrome c release. ${ }^{35}$ These results revealed that the treatment with DBID promotes apoptosis by alerting the $\mathrm{Bax} / \mathrm{Bcl} 2$ ratio by increasing the expression of Bax protein and down-regulating the expression of Bcl-2 as well as upregulating the genes involved in apoptosis. These findings of the current study are consistent with previous studies reported by several researchers. ${ }^{28-31,36,37}$

\section{Conclusions}

The present study demonstrates the antiproliferative activity of a new benzoindole derivative (DBID) against colon cancer cell line, HT-29, without being toxic to the normal colon cell (CCD $841 \mathrm{CoN})$. The quantitatively and qualitatively investigation of caspase activities by using luminescence spectrophotometry, fluorescence microscopy (AO/PI), flow cytometric Annexin V and gene expression provided in the present study, proposed that the antiproliferative effect of DBID on colon cancer cell line could be due to the occurrence of apoptosis through the generation of intracellular ROS, induction of cellular caspase activities as demonstrated by, initiation of both the intrinsic and extrinsic apoptosis pathways and upregulation of apoptotic genes. In conclusion, DBID which is a novel synthetic compound shows potential and promising chemotherapeutic properties.

\section{Acknowledgements}

This study was supported by University of Malaya Research Grants, PG073-2015B and RP043A-15HTM.

\section{References}

1 American Cancer Society, Cancer Facts \& Figures 2017, American Cancer Society, Atlanta, 2017.

2 B. Levin, D. A. Lieberman, B. McFarland, K. S. Andrews, D. Brooks, J. Bond, C. Dash, F. M. Giardiello, S. Glick, D. Johnson, C. D. Johnson, T. R. Levin, P. J. Pickhardt, D. K. Rex, R. A. Smith, A. Thorson and S. J. Winawer, Gastroenterology, 2008, 134, 1570-1595.

3 A. B. Benson, D. Schrag, M. R. Somerfield, A. M. Cohen, A. T. Figueredo, P. J. Flynn, M. K. Krzyzanowska, J. Maroun, P. McAllister and E. Van Cutsem, J. Clin. Oncol., 2004, 22, 3408-3419.

4 H. Patel, N. Darji, J. Pillai and B. Patel, Int. J. Drug Dev. Res., 2012, 2, 225-230.

5 N. Pahari, D. Saha, V. K. Jain, B. Jain and D. Mridha, Int. J. Pharm. Sci. Res., 2010, 1, 399-408.

6 M. M. Ibrahim, H. M. Ali, M. A. Abdullah and P. Hassandarvish, Molecules, 2012, 17, 12449-12459.

7 F. Hajiaghaalipou, F. Faraj, E. Bagheri, H. Khaledi, H. Ali, N. Majid and M. Abdulla, Curr. Pharm. Des., 2017, 1-10.

8 T. Mosmann, J. Immunol. Methods, 1983, 65, 55-63.
9 K.-B. Ng, A. Bustamam, M. A. Sukari, S. I. Abdelwahab, S. Mohan, M. J. C. Buckle, B. Kamalidehghan, N. M. Nadzri, T. Anasamy and A. H. A. Hadi, BMC Complementary Altern. Med., 2013, 13, 1.

10 F. Hajiaghaalipour, M. Kanthimathi, J. Sanusi and J. Rajarajeswaran, Food Chem., 2015, 169, 401-410.

11 A. Jarosz, M. Skoda, I. Dudek and D. Szukiewicz, Oxid. Med. Cell. Longevity, 2016, 2016, 1-14.

12 K. V. Sashidhara, A. Kumar, M. Kumar, J. Sarkar and S. Sinha, Bioorg. Med. Chem. Lett., 2010, 20, 7205-7211.

13 M. Hajrezaie, M. Paydar, S. Zorofchian Moghadamtousi, P. Hassandarvish, N. S. Gwaram, M. Zahedifard, E. Rouhollahi, H. Karimian, C. Y. Looi and H. M. Ali, Sci. World J., 2014, 2014, 1-12.

14 M. Zahedifard, F. L. Faraj, M. Paydar, C. Y. Looi, M. Hajrezaei, M. Hasanpourghadi, B. Kamalidehghan, N. A. Majid, H. M. Ali and M. A. Abdulla, Sci. Rep., 2015, 5, 11544.

15 W. M. Cholody, T. Kosakowska-Cholody, M. G. Hollingshead, H. K. Hariprakasha and C. J. Michejda, J. Med. Chem., 2005, 48, 4474-4481.

16 J. N. Weinstein, T. G. Myers, P. M. O'Connor, S. H. Friend, A. J. Fornace, K. W. Kohn, T. Fojo, S. E. Bates, L. V. Rubinstein and N. L. Anderson, Science, 1997, 275, 343-349.

17 H. U. Simon, A. Haj-Yehia and F. Levi-Schaffer, Apoptosis, 2000, 5, 415-418.

18 Y. M. Chung, Y. S. Bae and S. Y. Lee, Free Radical Biol. Med., 2003, 34, 434-442.

19 G.-Y. Liou and P. Storz, Free Radical Res., 2010, 44, 479-496. 20 J.-E. Ricci, R. A. Gottlieb and D. R. Green, J. Cell Biol., 2003, 160, 65-75.

21 D. Trachootham, J. Alexandre and P. Huang, Nat. Rev. Drug Discovery, 2009, 8, 579-591.

22 E. V. Mironova, A. A. Evstratova and S. M. Antonov, J. Neurosci. Methods, 2007, 163, 1-8.

23 L. von Bertalanffy, Protoplasma, 1963, 57, 51-83.

24 S. Fulda and K. M. Debatin, Oncogene, 2006, 25, 4798-4811. 25 M. E. l. Juan, U. Wenzel, H. Daniel and J. M. Planas, J. Agric. Food Chem., 2008, 56, 4813-4818.

26 C. Sanmartín, D. Plano, A. K. Sharma and J. A. Palop, Int. J. Mol. Sci., 2012, 13, 9649-9672.

27 P. J. Barnard and S. J. Berners-Price, Coord. Chem. Rev., 2007, 251, 1889-1902.

28 P. Beauparlant and G. Shore, Curr. Opin. Drug Discovery Dev., 2003, 6, 179-187.

29 C. Jiang, Z. Wang, H. Ganther and J. Lu, Cancer Res., 2001, 61, 3062-3070.

30 P. Hensley, M. Mishra and N. Kyprianou, Biol. Chem., 2013, 394, 831-843.

31 A. Philchenkov, M. Zavelevich, T. J. Kroczak and M. J. Los, Exp. Oncol., 2004, 26, 82-97.

32 A. Vazquez, E. E. Bond, A. J. Levine and G. L. Bond, Nat. Rev. Drug Discovery, 2008, 7, 979-987.

33 H. Li, H. Zhu, C.-j. Xu and J. Yuan, Cell, 1998, 94, 491501. 
34 S. Cory, D. C. Huang and J. M. Adams, Oncogene, 2003, 22, 36 E. Asselin, G. B. Mills and B. K. Tsang, Cancer Res., 2001, 61, 8590-8607. 1862-1868.

35 A. B. Parrish, C. D. Freel and S. Kornbluth, Cold Spring 37 M. Olsson and B. Zhivotovsky, Cell Death Differ., 2011, 18, Harbor Perspect. Biol., 2013, 5, 1-24. 1441-1449. 